\begin{tabular}{|c|c|c|c|c|c|c|}
\hline \multirow{4}{*}{ Impact Factor: } & ISRA (India) & $=3.117$ & SIS (USA) & $=0.912$ & ICV (Poland) & $=6.630$ \\
\hline & ISI (Dubai, UAE & $=0.829$ & РИНЦ (Russia) & $=0.156$ & PIF (India) & $=1.940$ \\
\hline & GIF (Australia) & $=0.564$ & ESJI (KZ) & $=8.716$ & IBI (India) & $=4.260$ \\
\hline & JIF & $=1.500$ & SJIF (Morocco) & $=5.667$ & OAJI (USA) & $=0.350$ \\
\hline
\end{tabular}

\section{SOI: $\underline{1.1 / T A S}$ DOI: $\underline{10.15863 / T A S}$ International Scientific Journal Theoretical \& Applied Science}

p-ISSN: 2308-4944 (print) e-ISSN: 2409-0085 (online)

Year: 2019 Issue: $06 \quad$ Volume: 74

Published: $19.06 .2019 \quad$ http://T-Science.org
QR - Issue

QR - Article
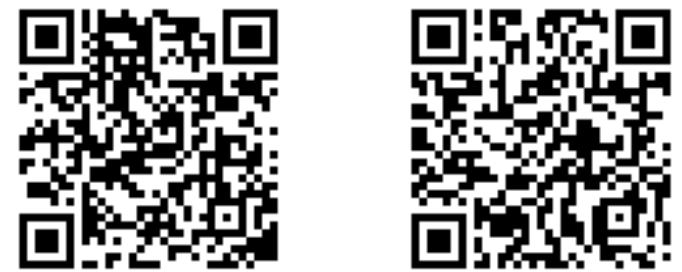

Norberto M. Secretaria Cebu Technological University A.B., M.B.A, PH.D. Social Sciences and Management Department College of Arts and Sciences, Cebu, Philippines (0938-224-3169)

norbertosecretaria@gmail.com

\title{
PRODUCT MARKETING SYSTEMS: THE CHALLENGE OF POVERTY AND THE CULTURE OF RESISTANCE AGAINST TECHNOLOGICAL CHANGE
} \begin{abstract}
afforded to those who cannot.
Language: English

\section{INTRODUCTION}

Farmers are the most significant element of the society since time immemorial. They feed the people, they fuel the economy. This is the reality that can never be denied. However, in developing countries like the Philippines, it displays a very different picture from that ideal sense. Farmers are seen as the least sector of the society, in fact the Philippine Statistics Authority published an article which provides that farmers are the poorest sector of the Philippine economy [1]. Added to the fact that there indeed is an
\end{abstract}

Abstract: Change is a deadly thing, it buries everyone who lag behind. It is precisely the reason why all have to embrace the virtue of continuous development. As for this study, it can be manifested in the form of adopting to the revolution of technology and rapid advancement of scientific inventions that change how agricultural products are developed and distributed along the supply chain. This paper presents the historical development of marketing systems, the challenges to development, and the adoption of technology in among the farmers, and find out whether or not there in fact, resistance in the technology adoption process. The data revealed that, the respondents are resistant to change in the cropping and harvest of farm products, as more farmers are inclined to remain using traditional methods of producing farm products. The agricultural marketing system in the Philippines continuously rely on traditional method despite the availability of modern marketing method. The farming sector is still the poorest sector of the Philippine society, and that the adoption of technological change is challenge by such a gruesome economic condition that continuously pounds the farmer's day-by-day life at the countryside. It is concluded that there indeed an observable culture of resistance to the adoption of technological change in the product marketing system, however, the most intervening factor in the inability of the farmers to adapt to change is the unavailability of resources due to poverty. It is recommended that the agriculture department and other concerned government agencies have to formulate a framework of development and devise means by which government resources are channeled well so as to impose change in the grassroots, and that available technology to those who can afford be

Key words: Poverty, Marketing, Technology, Technological Change, Marketing Systems, Agro-Product.

Citation: Secretaria, N. M. (2019). Product marketing systems: the challenge of poverty and the culture of resistance against technological change. ISJ Theoretical \& Applied Science, 06 (74), 318-324.

Soi: http://s-o-i.org/1.1/TAS-06-74-40 Doi: crossef https://dx.doi.org/10.15863/TAS.2019.06.74.40

observable delay in the penetration of technology in the Philippine agriculture sector[2], [3].

In this connection, this paper will present the current product marketing systems[4]-[6] attendant in the Philippine agribusiness market. As well as the totality of the technologies used as to the cropping and the harvesting method. The distribution strategies used, as well as the government aids received by the respondent farmers[7], [8]. This paper will also present the presence of resistance among farmers to adopt the available technology in product marketing[9], [10]. 


\begin{tabular}{|c|c|c|c|c|c|c|}
\hline \multirow{4}{*}{ Impact Factor: } & ISRA (India) & $=3.117$ & SIS (USA) & $=0.912$ & ICV (Poland) & $=6.630$ \\
\hline & ISI (Dubai, UAI & $=0.829$ & РИНЦ (Russia & $=0.156$ & PIF (India) & $=1.940$ \\
\hline & GIF (Australia) & $=0.564$ & ESJI (KZ) & $=8.716$ & IBI (India) & $=4.260$ \\
\hline & JIF & $=1.500$ & SJIF (Morocce & $=5.667$ & OAJI (USA) & $=0.350$ \\
\hline
\end{tabular}

Marketing is an encompassing field that harbors the totality of the product life cycle[11]. Product life is categorized into the following: Introduction, Growth, Maturity and Decline. In the development and the prototyping of the product, even idea in itself is considered part and parcel of the marketing management. Product marketing in the context of this study is the production, distribution and the consumption of vegetable consumers in the city of Cebu.

Production of agricultural products in the developing countries such as the Philippines is particularly challenging. The lack of resources and the enough knowledge in the modern technology is a continuing challenge. Added to the fact the Philippines is dubbed as the Typhoon capital of the world, amassing up to the average of 20 typhoons each year. Which typhoon Haiyan, the strongest typhoon, a category 5, to land on a body of soil, the City of Tacloban, just miles away from the locale of this study. This data is to emphasize that growing crops in this particular area are indeed very challenging if not, very difficult.

Part and parcel of that production challenge is the great necessity of the government aid that empowers the grassroots. Through the Department of Agriculture of The Philippines this paper presents the overview of how the government have exerted efforts in aid of the farmers in the midst of very challenging condition worsened by the drought as propelled by the Global Warming Phenomenon.

This paper further looked into the historical and the current product marketing systems attendant in the Philippine agribusiness market.

\section{METHODOLOGY}

This paper utilized descriptive method. The data was gathered through a survey method. The respondents were selected through random sampling. The respondents are farmers of 28 mountain villages of the City of Cebu, Philippines. No complex mathematical model was used. The numerical data gathered in this study was tested with statistical software, while textual data was analyzed through themes.

\section{RESULTS AND DISCUSSIONS}

It is very significant that no one will be left behind in the quest towards progress. It is a matter of right according to every human, so does the farmers in the context of this paper. At this point, this paper will present the presentation, analysis and the interpretation of the gathered data.

\section{Marketing Systems}

Traditional System. This is a kind of system since time immemorial. Characterized by farming manually, using buffalo or cows, delivering through manual carrying of the crops from the farms to the market[12]. In the age of technological advancement such a kind of method should have been faced out already. However, this kind of marketing system is prevalent in the Philippines where farmers plant, harvest, and deliver products in the traditional way[13]. Not only that it is very time consuming, it is also very inefficient[14].

Conventional Supermarket System. This system of product marketing is characterized by traditional brick and mortars stores that heavily relies on actual and free standing stores where the farm products are sold. Conventional supermarket systems are still prevalent today, anywhere in the world. In the United States, Wall Mart is the best example. In the Philippines, Save More Supermarkets, Metro and the like are those that belongs to the group. There is a problem with the supermarket systems, it requires considerable amount of financial capability to operate. It has limited reach, since it is almost always located only in metropolis.

Cluster Farming System. It is a system that aims at sustainability. Bruntland Report, coined that "Sustainable development is a development that meet the needs of the present without compromising the ability of the future to meet their own needs". Basically, this system is aimed at sustainable agriculture[15], [16]. This system is also used in the southern Philippines in the island of Mindanao. It helped the farmers to earn more without necessarily endangering the environment. Additionally, this system supports the farmers from, production, postharvest handling, trading, processing, Re-trading, retailing and consumption. Along the way towards the end consumer it is ensured that all elements aligned well so as sustainability is achieved.

Agricultural Marketing Information System. A system characterized by modernity where technology is imbedded in the heart of agribusiness. Farmers in this system are connected with a web server and all information are readily available. In this system, all Seed Sellers, Agricultural Advisories, Administrators are connected to a database[17]. This is also connected to the cloud where data delivery is very fast. Data from this system can also serve as basis for strategic decision making casted by the Agriculture Department. This is also a very expensive kind of system. It has not yet penetrated into the Philippines.

E-commerce System. This system is characterized by modernity where consumers do not necessarily have to go to a market, just a mere tap of the hand, order it online, and the farm products are deliver right on the consumers doorstep[18], [19].

There may be other systems available in the world, but such is too long to mention, this research leave it there. It can be noted however, that among all the marketing system available, the most attendant system is the traditional one.

\section{Cropping Technology}

The table below provides information on how farmers plant their crops, as well how they harvest the 


\begin{tabular}{|c|c|c|c|c|c|c|}
\hline \multirow{4}{*}{ Impact Factor: } & ISRA (India) & $=3.117$ & SIS (USA) & $=0.912$ & ICV (Poland) & $=6.630$ \\
\hline & ISI (Dubai, UAI & $=0.829$ & РИНЦ (Russia & $=0.156$ & PIF (India) & $=1.940$ \\
\hline & GIF (Australia) & $=0.564$ & ESJI (KZ) & $=8.716$ & IBI (India) & $=4.260$ \\
\hline & JIF & $=1.500$ & SJIF (Morocce & $=5.667$ & OAJI (USA) & $=0.350$ \\
\hline
\end{tabular}

same. The questions are divided into two aspects, the modern and the traditional methods.

The first six items of Table 1 presents the farmer's use of modern technology for cropping or planting. The data reveal that the farmer does not use tractors at all with the mean of 4.24 which means that farmers do not use tractors in the cultivation of their farms. No greenhouse facilities, no automated harvesting method, they rarely use mulching technology, and only uses water pumps sometimes. The same with the mean of, 4.73, 4.85, 3.41, 2.93 and 3.88 respectively.

Table No. 1 Cropping Technology

\begin{tabular}{|c|c|c|c|c|}
\hline & Mean & $\begin{array}{l}\text { Std. } \\
\text { Deviation }\end{array}$ & Interpretation & Ave. Mean \\
\hline 1. Tractors are used in cultivating my farm. & 4.24 & 1.132 & Never & \multirow{5}{*}{$\begin{array}{l}4.01 \\
\text { Rarely }\end{array}$} \\
\hline 2. Green house are used for plant protection & 4.73 & 0.782 & Never & \\
\hline 3. I use automated planting technology & 4.85 & 0.588 & Never & \\
\hline $\begin{array}{l}\text { 4. I use Mulching Technology to protect } \\
\text { plans from weeds }\end{array}$ & 3.41 & 1.498 & Rarely & \\
\hline $\begin{array}{l}\text { 5. Water pumps are used in watering the } \\
\text { plants }\end{array}$ & 2.93 & 1.662 & Sometimes & \\
\hline 6. I use drip irrigation in my farm & 3.88 & 1.384 & Rarely & \multirow{7}{*}{$\begin{array}{l}1.81 \\
\text { Often }\end{array}$} \\
\hline 7. Still using carabao in farming & 2.45 & 1.525 & Often & \\
\hline 8. Plants have no protection, rain or shine & 2.15 & 1.469 & Often & \\
\hline 9. Still utilize Manual planting of my crops & 1.49 & 0.993 & Always & \\
\hline 10. I use upland spring for water source & 1.79 & 1.917 & Always & \\
\hline 11. Manual watering of the plant & 1.54 & 0.986 & Always & \\
\hline 12. Weeding is still manual using bolos & 1.43 & 0.917 & Always & \\
\hline
\end{tabular}

*1-6 Modern, 7-12 Traditional methods

On the second part of Table 1 shows the cropping technology using the traditional method. The data reveal that farmers still use Carabao, manual planting, and spring as a water source, manual watering, and weeding using Bolos. With mean of $2.45,2.15,1.49,1.79,1.54$ and 1.43 respectively.

With the available data, the average mean can be derived to represent the entire respondents' responses in this context. Table 1 presents the average mean in both traditional and modern methods of cropping. The table also presents the mean comparison between the modern and traditional method of cropping. The data reveal that the farmers are still using traditional methods of cropping. This means that the farmers are unable to arrive at the maximum potential of productivity due to Equipment Constraints and the methods used in the planting products. Farming equipment deeply affects productivity [20]

\section{Harvest Technology}

Without investing in modern post-harvest equipment and methods the farmers will continue to suffer from losses, sometimes great losses that can cause tremendous financial backlogs for farmers. This is because the greatest value loss suffered by farmers are in the post-harvest period in the cropping season. With the data, it can be assumed that farmers are suffering from loss of value of the product they produce due to the absence of the post-harvest system. Corporate Document Repository of the Food and Agriculture Organization estimates that the loss in the post-harvest period can climb up to a stunning $30 \%$ of the plant harvested.

Table 2 presents the methods of harvest used by the farmers in the conduct of their farming activities. The questions are divided into two categories modern methods and traditional method.

The table also presents the summary of responses by mean in the question of whether or not the farmers use modern methods of farming still remains in traditional methods. The data reveal that farmers never use modern methods and equipment in the harvesting of crops. With the average mean of 4.60 , it can be interpreted as 'Never' through the use of the scoring procedure. On the other hand, the traditional methods of harvesting such as the use of Sacks and Bakat (Bamboo Crates) still prevail within the agricultural market system in the City. The traditional method has an average mean of 1.85 which 


\begin{tabular}{|c|c|c|c|c|c|c|}
\hline \multirow{4}{*}{ Impact Factor: } & ISRA (India) & $=3.117$ & SIS (USA) & $=0.912$ & ICV (Poland) & $=6.630$ \\
\hline & ISI (Dubai, UAI & $=0.829$ & РИНЦ (Russia & $=0.156$ & PIF (India) & $=1.940$ \\
\hline & GIF (Australia) & $=0.564$ & ESJI (KZ) & $=8.716$ & IBI (India) & $=4.260$ \\
\hline & JIF & $=1.500$ & SJIF (Morocce & $=5.667$ & OAJI (USA) & $=0.350$ \\
\hline
\end{tabular}

can be interpreted as 'Often'. Meaning, the farmers often use traditional methods of harvesting the crops produce on farms.

Table No. 2 Harvest Technology

\begin{tabular}{|c|c|c|c|c|}
\hline & Mean & Std. Deviation & Interpretation & Ave. Mean \\
\hline $\begin{array}{l}\text { 1. Harvested crops are put on } \\
\text { trays/cartoon/crates }\end{array}$. & 4.22 & 1.23 & Never & \multirow[t]{6}{*}{$\begin{array}{l}4.60 \\
\text { Never }\end{array}$} \\
\hline 2. Customized packaging design is used & 4.71 & 0.762 & Never & \\
\hline 3. Harvesting is automated & 4.87 & 0.569 & Never & \\
\hline $\begin{array}{l}\text { 4. Refrigerated storage are used to preserve } \\
\text { freshness }\end{array}$ & 4.87 & 0.602 & Never & \\
\hline $\begin{array}{l}\text { 5. Harvest are processed before delivery as } \\
\text { final product }\end{array}$ & 4.69 & 0.871 & Never & \\
\hline $\begin{array}{l}\text { 6. Modified atmospheric packaging is used } \\
\text { to prolong shelf life of the harvest }\end{array}$ & 4.77 & 0.849 & Never & \\
\hline $\begin{array}{l}\text { 7. Basket and sacks are used for harvested } \\
\text { crops }\end{array}$ & 1.73 & 1.08 & Always & \multirow[t]{6}{*}{$\begin{array}{l}1.85 \\
\text { Often }\end{array}$} \\
\hline $\begin{array}{l}\text { 8. Harvest are sent to the city without any } \\
\text { packaging }\end{array}$ & 2.42 & 1.329 & Often & \\
\hline 9. Harvesting is done manually & 1.68 & 1.175 & Always & \\
\hline 10. Product are sold directly to avoid spoilage & 1.79 & 1.066 & Always & \\
\hline $\begin{array}{l}\text { 11. What is harvested is considered final } \\
\text { product }\end{array}$ & 1.7 & 1.062 & Always & \\
\hline 12. Our harvest cannot be stored very long & 1.84 & 1.21 & Often & \\
\hline
\end{tabular}

*1-6 Modern, 7-12 Traditional

\section{Alternative Transport}

Table 3 presents the alternative transportation used by the farmers in the delivery of the products to the market and the customers. Paying for the transportation comprises the total 83 responses, or $53.2 \%$ of the total respondents rely on. Selling the products to wholesalers is the second in the rank, of 81 responses or $51.9 \%$ of the total respondents rely on. Customers getting the harvest is 39 , Selling to persons with transport vehicles at 38, and lastly, the Government provided vehicles at 30 , or $19.2 \%$

\section{Table 3. Alternative Transportation}

\begin{tabular}{|l|l|l|}
\hline Alternatives & f & Rank \\
\hline Pay for transportation from farm to the city & 83 & 1 \\
\hline Sell to wholesalers so that I will not have problem with transportation & 81 & 2 \\
\hline Customers get the harvest from my house & 39 & 3 \\
\hline Sell farm product to those who have transport vehicles & 38 & 4 \\
\hline Use government provided vehicles & 30 & 5 \\
\hline
\end{tabular}

The data should mean to provide the government with an exact message that it should develop more projects about the advancement of transportation in aid of the farmers who do not have personal vehicles. The government is the parens paterae of the state should invest more in transportation and other modes to help the farmer's transport products from farm to the customers.

This is because, an improved transportation will encourage farmers to go harder in the rural areas for increased yield, add value to their products, reduce spoilage and wastage, empower the farmers as easily as possessing a positive impact on their productivity, income, employment and reduce poverty level in the rural areas since it will be more comfortable to move inputs and workers to farm as well as products to markets and agro-allied industry (Ajibuye and Afolayan, 2009).

Government policies are also aspects that needs consideration in the study of productivity of farmers 


\begin{tabular}{llllll} 
& ISRA (India) $=\mathbf{3 . 1 1 7}$ & SIS (USA) $=\mathbf{0 . 9 1 2}$ & ICV (Poland) & $\mathbf{= 6 . 6 3 0}$ \\
Impact Factor: & ISI (Dubai, UAE) $=\mathbf{0 . 8 2 9}$ & PUHЦ (Russia) $=\mathbf{0 . 1 5 6}$ & PIF (India) & $=\mathbf{1 . 9 4 0}$ \\
& GIF (Australia) $=\mathbf{0 . 5 6 4}$ & ESJI (KZ) & $\mathbf{8 . 7 1 6}$ & IBI (India) & $\mathbf{4 . 2 6 0}$ \\
& JIF & $\mathbf{1 . 5 0 0}$ & SJIF (Morocco) $=\mathbf{5 . 6 6 7}$ & OAJI (USA) & $\mathbf{= 0 . 3 5 0}$ \\
\hline
\end{tabular}

in the city. Among these policies are the following: Government Program of Farm Inputs, Farm Monitoring and Method of Farming.

\section{Government Programs on Farm Inputs}

The government has established methods of giving aides to the deserving farmers in the City. They have provided relevant farm inputs to the farmers to mobilize productivity. The data revealed that the governmental aides are present and is provided to the farmers in the City of Cebu. The data showed that more than a thousand units or fertilizers were given to the farmers to help them in the production of vegetables in the mountain barangays of the City. Seeds 729, Pesticides 434, Drums 253, Hose 133 and the least is Carabao at three units. The data means that despite limited resources from the government several farm inputs were validly received and had helped the farmers in farming.

The method of allowed farming is very crucial to the outcome and output of farm products. There are several methods adopted by the department of agriculture; it includes the following: Pure organic, the one being pushed at the moment. Pure Chemical the one in the process of extinction for the system. And third, is Good Agricultural Practice which is a substantial combination of the two. Pure organic has a frequency of 16 or $8.7 \%$, Pure Chemical has a frequency of 21 or $11.4 \%$ and lastly, Good agricultural Practice at 119 or $64.7 \%$. The data reveal that more farmers are practicing Good Agricultural Practice which means that consumers of farm products within the City can expect a fresh and safer food out from our farms.

Poverty

The agriculture is the hardest hit sector of the community when dealing with extreme poverty. This case is true not only in the Philippines but also to the world, especially when studying the cases in the third world countries or those that are developing and rising economies. It is apparent that the sector that provides foods to the table are more often the ones left behind.

Statistical data show that among the poorest people on the planet, farmers set on the top (see Figure No. 13). Based on the figure from the Philippines Statistics Authority, fishers and farmers in the Philippines are the most unfortunate people in the primary sectors, with poverty incidence at 39.2 and 38.3 respectively. The said figure is way beyond the national poverty incidence average point of 25.2 points. The same data shows that 2.8 percent of poverty incidence in the fishing, and 0.3 percent in the farming sector. This data statistic means that farmers and fishermen are not only the poorest sectors of our society, it is also becoming poorer and poorer.

Based on the January 2017 Labor Force Survey, the unemployment rate in the country increased to 6.6 percent in January 2017. This is higher than the 5.7 percent recorded in January 2016. The agriculture sector accounted for the second-largest share of employment in the country at 25.5 percent. This means that the sector has shed an estimated 882,000 workers or two-thirds of total employment losses.

\section{Resistance to Change}

As this paper provided in the first part of this paper, that change is the only way to go in this very competitive world, this research goes deeper into the very heart of the problem, questioning exactly what hinders the farmers from adopting the modern technology in agribusiness product marketing. Questions were propounded to the selected respondent farmers on the probable reasons, and to determine whether or not there indeed is an observable resistance to change. The data revealed based on the following themes: Ignorance to technological availability, Lack of knowledge, Expensive, Used to traditional way, and Lack of Money.

The primary consideration of as to the reason why the data previously presented is inclined into the traditional way despite of the availability of government aid is the lack of knowledge that such technology is available for use, a respondent says " $\mathrm{Wa}$ koy idea nga naa diay ingon ana nga teknolohiya" (I do not have any idea that there is such technology). The data implies that there is problem in the farmers' education on the modern technology that are available. If the respondent farm have the necessary tool as may be provided by the government, a respondent added that, "Di ko kamao mo gamit, or ug mo gamit man gani, mahadlok kay maguba nya, makabayad tas association" (I do not know how to use it, if we knew, we rather not use it. We are afraid that it might be damaged and we have to pay the price in the farmers' association). The respondents are afraid of using the available technology since they do not own it, and the farmers organization do, and so if the same will be damaged during their use, they have to pay it, and so the best method is not to use it anyway.

Poverty is also a factor as to why these respondents seems to resist technological change, as previously pointed out in this paper, that farmers are the poorest sector of the Philippine society, it also reflected on the respondent response, "Wa mi ika palit sir, way igong kwarta para mo adap ug bago nga teknolohiya sa pag tanum ug pamaligya, mas importante ang pagkaon" (We do not have enough money sir, to adapt modern cropping and marketing technologies, food is more important). It can be observed in this response that farmers would rather focus on the provision of food for the family than investing for the farm technologies that they may market their produce at par with industrial farms. 


\begin{tabular}{|c|c|c|c|c|c|c|}
\hline \multirow{4}{*}{ Impact Factor: } & ISRA (India) & $=3.117$ & SIS (USA) & $=0.912$ & ICV (Poland) & $=6.630$ \\
\hline & ISI (Dubai, UAI & $=0.829$ & РИНЦ (Russia & $=0.156$ & PIF (India) & $=1.940$ \\
\hline & GIF (Australia) & $=0.564$ & ESJI (KZ) & $=8.716$ & IBI (India) & $=4.260$ \\
\hline & JIF & $=1.500$ & SJIF (Morocce & $=5.667$ & OAJI (USA) & $=0.350$ \\
\hline
\end{tabular}

A clear resistance to change was propounded by a respondent, "Di lang ko mo gamit anang ilang ingon nga unsa na, kay na anad na mi ani among pamaagi, gikan pa nis among mga katiguwangan." (I would rather not use that modern method, we are used to this way, because we inherited this from our forefathers). In this particular response it can be observed well, that there indeed is resistance to change in the product marketing in agribusiness in Cebu City, although this response may not represent the totality of the entire farmer's population, it should be noted that a great number of the said group shares the same idea about change.

\section{CONCLUSION}

It is concluded that there indeed an observable culture of resistance to the adoption of technological change in the product marketing system, however, the most intervening factor in the inability of the farmers to adapt to change is the unavailability of resources due to poverty.

\section{RECOMMENDATION}

In line with the UN Sustainable Development Goal of Zero Poverty and Sustainable Community. It is recommended that the agriculture department and other concerned government agencies to formulate a framework of development and devise means by which government resources are channeled well so as to impose change in the grassroots, and that available technology to those who can afford be afforded to those who cannot. This does not work only for the Philippines but for all countries in the world where there is great need to empower to poorest of the poor, in order that distribution of resources be equalized by the propellant power of social justice.

The Universities and Colleges in the Philippines have to aid in the education of farmers in the fulfillment of its mandate to provide extension programs that help uplift the living standards of the community.

\section{References:}

1. AMIS. (2019). Agricultural Market Information System: Home. Retrieved June 17, 2019, from http://www.amis-outlook.org/

2. Andersen, E. (2017). The farming system component of European agricultural landscapes. European Journal of Agronomy, 82, 282-291. https://doi.org/10.1016/J.EJA.2016.09.011

3. Awotide, B. A., Karimov, A. A., \& Diagne, A. (2016). Agricultural technology adoption, commercialization and smallholder rice farmers' welfare in rural Nigeria. Agricultural and Food Economics, $4(1)$, https://doi.org/10.1186/s40100-016-0047-8

4. Briggeman, B. C., \& Whitacre, B. E. (2010). Farming and the Internet: Reasons for Non-Use. Agricultural and Resource Economics Review, 39(03), 571-584. https://doi.org/10.1017/S1068280500007528

5. Fecke, W., Danne, M., \& Musshoff, O. (2018). E-commerce in agriculture - The case of crop protection product purchases in a discrete choice experiment. Computers and Electronics in Agriculture, 151, 126-135. https://doi.org/10.1016/J.COMPAG.2018.05.03 2

6. Huffman, W. E. (1996). Modernizing Agriculture: A Continuing Process. Daedalus.
The MIT PressAmerican Academy of Arts \& Sciences. https://doi.org/10.2307/20027527

7. Jamaluddin, N. (2013). Adoption of Ecommerce Practices among the Indian Farmers, a Survey of Trichy District in the State of Tamilnadu, India. Procedia Economics and Finance, 7, 140-149. https://doi.org/10.1016/S2212-5671(13)00228-1

8. Jeon, J., Gwon, S.-H., \& Cho, J. (2018). A Dynamic Diffusion of Mobile Phone in Korea: Focused on Traditional Marketing Activities and Online Word-of Mouth. International Journal of Advanced Science and Technology, 113, 143152. https://doi.org/10.14257/ijast.2018.113.15

9. Kadirov, D., \& Varey, R. J. (2011). Symbolism in Marketing Systems. Journal of Macromarketing, 31(2), 160-171. https://doi.org/10.1177/0276146710393519

10. Kirchweger, S., \& Kantelhardt, J. (2015). The dynamic effects of government-supported farminvestment activities on structural change in Austrian agriculture. Land Use Policy, 48, 7393.

https://doi.org/10.1016/j.landusepol.2015.05.00 5

11. Layton, R. A. (2009). On Economic Growth, Marketing Systems, and the Quality of Life. 


\begin{tabular}{|c|c|c|c|c|c|c|}
\hline \multirow{4}{*}{ Impact Factor: } & ISRA (India) & $=3.117$ & SIS (USA) & $=0.912$ & ICV (Poland) & $=6.630$ \\
\hline & ISI (Dubai, UAI & $=0.829$ & РИНЦ (Russia & $=0.156$ & PIF (India) & $=1.940$ \\
\hline & GIF (Australia) & $=0.564$ & ESJI (KZ) & $=8.716$ & IBI (India) & $=4.260$ \\
\hline & JIF & $=1.500$ & SJIF (Morocce & $=5.667$ & OAJI (USA) & $=0.350$ \\
\hline
\end{tabular}

Journal of Macromarketing, 29(4), 349-362. https://doi.org/10.1177/0276146709345108

12. Layton, R. A. (2015). Formation, Growth, and Adaptive Change in Marketing Systems. Journal of Macromarketing, 35(3), 302-319. https://doi.org/10.1177/0276146714550314

13. PSA. (2017). Farmers, Fishermen and Children consistently posted the highest poverty incidence among basic sectors - PSA | Philippine Statistics Authority. Retrieved November 16, 2018, from https://psa.gov.ph/content/farmers-fishermenand-children-consistently-posted-highestpoverty-incidence-among-basic

14. Sajjad, H., \& Nasreen, I. (2016). Assessing farmlevel agricultural sustainability using sitespecific indicators and sustainable livelihood security index: Evidence from Vaishali district, India. Community Development, 47(5), 602619.

https://doi.org/10.1080/15575330.2016.122143 7

15. Sipahutar, H. (2016). Factors Affecting Traditional Markets Competitiveness. Jurnal Bina Praja, 08(01), 27-38. https://doi.org/10.21787/JBP.08.2016.27-38

16. Srinivasan, S., Rutz, O. J., \& Pauwels, K. (2016). Paths to and off purchase: quantifying the impact of traditional marketing and online consumer activity. Journal of the Academy of Marketing
Science, 44(4), 440-453. https://doi.org/10.1007/s11747-015-0431-z

17. Wyche, S., \& Steinfield, C. (2016). Why Don't Farmers Use Cell Phones to Access Market Prices? Technology Affordances and Barriers to Market Information Services Adoption in Rural Kenya. Information Technology for Development, 22(2), 320-333. https://doi.org/10.1080/02681102.2015.104818 4

18. Xu, J. (2018). Research on Enterprise Marketing Strategy Based on Product Life Cycle Theory. In Proceedings of the 8th International Conference on Social Network, Communication and Education (SNCE 2018). Paris, France: Atlantis Press. https://doi.org/10.2991/snce-18.2018.138

19. Ye, T., Hu, W., Barnett, B. J., Wang, J., \& Gao, Y. (2019). Area Yield Index Insurance or Farm Yield Crop Insurance? Chinese Perspectives on Farmers' Welfare and Government Subsidy Effectiveness. Journal of Agricultural Economics, 1477-9552.12326. https://doi.org/10.1111/1477-9552.12326

20. Zeng, Y., Jia, F., Wan, L., \& Guo, H. (2017). Ecommerce in agri-food sector: a systematic literature review. International Food and Agribusiness Management Review, 20(4), 439460. https://doi.org/10.22434/IFAMR2016.0156 